\title{
FAKTOR EMOTIF DALAM KUMPULAN PUISI HUJAN BULAN JUNI KARYA SAPARDI DJOKO DAMONO
}

\author{
Mohammad Irwan Syafi' i, Nita Widiati \\ Universitas Negeri Malang
}

\begin{tabular}{|c|c|}
\hline A R T I K E L & A B S T R A K \\
\hline $\begin{array}{l}\text { Kata Kunci: } \\
\text { faktor emotif } \\
\text { puisi } \\
\text { nilai emotif }\end{array}$ & $\begin{array}{l}\text { Penelitian ini bertujuan untuk menjelaskan faktor emotif dan nilai emotif yang digunakan } \\
\text { dalam kumpulan puisi Hujan Bulan Juni. Penelitian ini menggunakan pendekatan } \\
\text { deskriptif kualitatif dengan jenis analisis dokumen. Data penelitian ini adalah larik puisi } \\
\text { yang mengandung faktor dan nilai emotif. Sumber datanya adalah kumpulan puisi Hujan } \\
\text { Bulan Juni karya Sapardi Djoko Damono. Hasil penelitian menunjukkan adanya } \\
\text { penggunaan faktor emotif diksi, kata konkret, imaji, majas, bunyi, dan sarana retorik untuk } \\
\text { menghasilkan nilai emotif dalam kumpulan puisi ini. }\end{array}$ \\
\hline
\end{tabular}

\section{A R T I C LE IN F O}

\section{Keywords: \\ emotive factor \\ poetry}

emotive value

\section{A B S T R A C T}

This study aims to explain emotive factors and emotive values used in the Hujan Bulan Juni poetry collections. This research uses qualitative descriptive approach with document analysis type. The data of this research is a line of poetry containing emotive factor and value. The source of the data is a Hujan Bulan Juni poetry collections by Sapardi Djoko Damono. The results showed the use of emotive diction factors, concrete words, images, majas, sounds, and rhetorical means to produce emotive value at this poetry collection.

(C) 2017 BASINDO Journal. All rights reserved

\section{PENDAHULUAN}

Puisi sering menggunakan berbagai perangkat bahasa untuk merangkai kata-kata yang indah. Perangkat bahasa yang digunakan untuk merangkai kata-kata tersebut, boleh saja diselewengkan atau tidak mengikuti bentukan kata sesuai dengan pedoman ejaan yang disempurnakan. Terkadang juga terdapat penghilangan bunyi dalam puisi untuk membentuk kata-kata yang indah. Tujuan dari pembentukan kata yang indah tersebut tidak lain adalah untuk menyampaikan perasaan penyair.

R. Delacroix (dalam Ullman, 2014:157) menyatakan bahwa tiap bahasa memiliki nilai emotif dan bermaksud untuk mengomunikasikan sesuatu, andai perkataan tersebut tidak cocok baginya atau memang tidak ada tujuan untuk mengatakan sesuatu maka dia akan memilih untuk tidak berkata apapun. Hal ini menunjukkan bahwa dalam setiap tindak berbahasa, termasuk dalam puisi, tentu ada faktor emotif dan nilai emotif ini yang ditujukan oleh penyair tehadap pembaca. Hanya saja dalam memaknai puisi kita harus memaknai ulang makna harfiahnya, karena puisi merupakan sistem tanda tingkat kedua yang mempergunakan medium bahasa (Pradopo, 1987: 209).

Penelitian terdahulu terkait dengan penelitian ini adalah sebagai berikut.

Pertama, Oki Maria Fransiska (2010) dalam skripsinya yang berjudul Penggunaan Gaya Bahasa Kias Pada Novel Sang Pemimpi Tetralogi (Kajian Stilistika) Karya Andrea Hirata menyatakan bahwa "Penggunaan gaya bahasa dalam karya sastra khususnya novel berfungsi menimbulkan efek estetis, membangkitkan suasana, kesan, dan tanggapan indera tertentu." Kedua, Moh. Fikri Zulfikar (2014) dalam skripsinya yang berjudul Ekspresi Pengalaman Kejiwaan Penulis Puisi dalam Majalah Bobo menyatakan bahwa "Puisi adalah salah satu karya sastra yang dapat dipandang sebagai ekspresi dunia batin penulis, salah satunya ditunjukkan dengan ekspresi pengalaman kejiwaan melalui kata

\footnotetext{
${ }^{*}$ Corresponding author.

E-mail addresses: emwan64@gmail.com (Mohammad Irwan Syafi' i), nitawidiatie7sa@gmail.com (Nita Widiati)
} 
dan kalimat dalam bait puisi." Ketiga, Dian Fitra Fajarina juga menganalilis emotif atau kejiwaan seorang pengarang naskah drama dengan judul Ekspresi pengalaman kejiwaan pengarang dalam naskah drama Indonesia. Dalam proses pengekspresian pengalaman kejiwaan dalam naskah drama, pada umumnya pengarang menggunakan lambang kebahasaan. Oleh karena itu, pemaknaan terhadap lambang kebahasaan tersebut diperlukan untuk menginterpretasi ekspresi pengalaman kejiwaan pengarang.

Masalah pada penelitian ini adalah (1) faktor emotif apa saja yang digunakan dalam puisi Pada Suatu Hari Nanti karya Sapardi Djoko Damono dan (2) nilai emotif apa saja yang terdapat dalam puisi Pada Suatu Hari Nanti karya Sapardi Djoko Damono.

Tujuan penelitian ini adalah untuk (1) menjelaskan faktor emotif yang digunakan dalam puisi Pada Suatu Hari Nanti karya Sapardi Djoko Damono dan (2) menjelaskan nilai emotif yang terdapat dalam puisi Pada Suatu Hari Nanti karya Sapardi Djoko Damono. Manfaat penelitian ini dapat diklasifikasikan menjadi dua, yakni manfaat praktis dan teoritis. Manfaat praktis pada penelitian ini ada dua, yakni: (1) manfaat bagi peneliti adalah untuk menambah wawasan tentang faktor emotif dalam puisi dan (2) manfaat bagi pihak yang diteliti adalah untuk memantau penggunaan faktor emotif dalam puisinya serta dapat pula sebagai bahan kajian dalam mengembangkan teknik penggunaan faktor emotif dalam puisi berikutnya. Manfaat teoritisnya ada tiga, yakni: (1) memberikan sumbangan pengetahuan terhadap pengembangan bidang kepenulisan puisi, (2) kontribusi mengetahui teori penggunaan faktor emotif, jenis-jenis perabot emotif yang digunakan, serta emosi yang dihasilkan dari penggunaan perabot emotif dalam puisi, dan (3) memperluas pemahaman pada realita praktik penggunaan faktor emotif dalam bidang kepenulisan puisi.

Dari latar belakang di tersebut, maka dapat disimpulkan bahwa penelitian ini adalah penelitian baru karena sebelunya belum pernah diteliti. Penelitian ini dilatar belakangi oleh faktor emotif sehingga dalam mengkaji puisinya pun akan dikaji dengan pendekatan emotif, yakni lebih menekankan ada pengalaman kejiwaan. Penelitian ini akan mengkaji faktor emotif yang terdapat dalam kumpulan puisi Hujan Bulan Juni karya Sapardi Djoko Damono.

\section{METODE}

Desain penelitian ini adalah kualitatif. Pendekatan kualitatif adalah suatu prosedur penelitian yang terjadi secara alamiah, apa adanya, dalam situasi normal yang tidak dimanipulasi keadaan dan kondisinya, menekankan pada deskripsi secara alami (Arikunto, 2010: 12). Penelitian ini bersifat deskriptif karena adanya upaya mengolah data menjadi sesuatu yang dapat diutarakan secara jelas dan tepat dengan tujuan agar dapat dimengerti oleh orang lain. Jenis penelitian ini adalah studi kepustakaan atau dokumen. Metode kepustakaan/dokumen adalah salah satu jenis metode penelitian kualitatif yang lokasi atau tempat penelitiannya dilakukan di pustaka, dokumen, arsip, dan lain sejenisnya. Atau dengan kata lain, metode penelitian ini tidak menuntut peneliti terjun ke lapangan melihat fakta langsung sebagaimana adanya (Prastowo, 2014:190).

Objek penelitian yang dipilih adalah puisi Pada Suatu Hari Nanti karya Sapardi Djoko Damono. Penelitian ini memilih puisi tersebut karena puisi tersebut adalah jenis puisi yang menggunakan berbagai struktur fisik yang menarik. Berbagai perabot emotif digunakan dalam puisi-puisi yang berada di dalamnya, hal ini diperkirakan akan memperkaya hasil penelitian. Puisi tersebut adalah puisi yang tingkat musikalitasnya tinggi sehingga sering digunakan untuk musikalisasi puisi. Penelitian ini semakin memperkaya kajian perabot emotif berupa bunyi dalam penelitian ini.

\section{HASIL DAN PEMBAHASAN}

\section{Faktor Emotif dalam Kumpulan Puisi "Hujan Bulan Juni" Karya Sapardi Djoko Damono}

Seperti halnya genre teks dan karya sastra lain, puisi juga memiliki faktor emotif. Bedanya, dalam genre teks dan karya satra lain faktor emotif dapat ditemukan dalam slogan dan lain-lain, sedangkan dalam puisi karena maknanya disembunyikan, maka faktor emotif tersebut dapat terlihat di unsur intrnsiknya. Berikut ini adalah beberapa faktor emotif yang terdapat dalam kumpulan puisi "Hujan Bulan Juni" karya Sapardi Djoko Damono.

\section{Tipografi}

Dalam puisi, terkadang penulis membuat tipografi tertentu dalam menyampaikan makna tersiratnya. Berikut ini adalah contoh penggunaan tipografi.

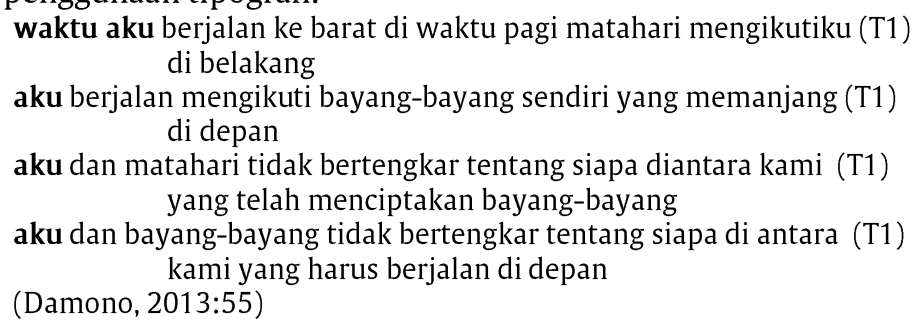

Menurut Wisang (2014:32) "tipografi akan menampilkan aspek visual artistik dan menciptakan nuansa makna dan suasana tertentu." Pada penggalan puisi berjudul "Berjalan ke Barat Waktu pagi Hari" di atas terdapat penonjolan pada kata waktu aku dan aku yang menunjukkan hubungan si aku dengan hal-hal di sekelilingnya. Penonjolan tersebut menunjukkan hubungan harmonis antara si aku dengan matahari dan bayang-bayang. Pada hubungan tersebut menunjukkan betapa ikhlas dan tulusnya hubungan antara ketiganya dalam menghadapi kehidupan.

\section{Diksi}

Diksi adalah pilihan kata yang digunakan oleh penulis untuk memperindah puisi. Puisi bukanlah teks formal sehingga penulis tak harus melakukan kaidah bahasa sebagaimana digunakan dalam teks-teks lainnya. Dalam diksinya, penulis biasanya melakukan penyimpangan-penyimpangan yang tidak sesuai dengan kaidah bahasa. Geoffry (dalam 
Siswanto, 2013:105) menyatakan adanya beberapa penyimpangan yang sering dijumpai dalam puisi. Berikut ini adalah beberapa penyimpangan yang biasa dilakukan oleh penyair.

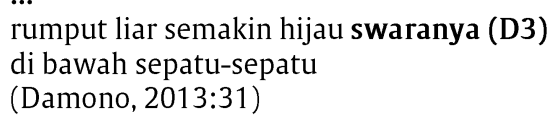

Pertama adalah penyimpangan fonologis. Penggalan puisi berjudul "Bunga-bunga Di Halaman" di atas juga menunjukkan adanya penyimpangan penggunaan kaidah bahasa berupa penyimpangan fonologis. Penyimpangan fonologis biasanya terjadi dengan cara mengurangi, menambahkan maupun mengganti fon dalam kata tertentu. Dalam puisi di atas kata suara diganti dengan swara untuk menambahkan nilai estetis.

(malam berkabut seketika); barangkali menjemputku

Barangkali berkabar penghujan itu. (D4)

(Damono, 2013:30)

Kedua adalah penyimpangan morfologis. Penggalan puisi "Kupandang Kelam Yang Merapat ke Sisi Kita" di atas memiliki penyimpangan pada penggunaan imbuhan ber- pada kata berkabar. Hal itu digunakan penyair untuk mendapatkan fungsi memberikan sehingga menjadi barangkali memberikan kabar penghujan itu.

ketika kusebut berulang nama-Mu: taram- (D8)

temaram bayang bianglala itu (D8)

(Damono, 2013:2)

Ketiga adalah penyimpangan historis. Dalam puisi berjudul "Sajak Desember" di atas, pengarang menggunakan kata-kata yang sudah jarang digunakan lagi untuk memperindah puisnya. Kata taram-temaran memiliki nilai historis yang artinya adalah suatu keadaan atau suasana dikala siang akan berganti malam, atau suasana disaat matahari akan tenggelam di ufuk barat dan akan datang gelap (remang-remang). Kata bianglala memiliki nilai historis yang artinya pelangi. Hal ini menunjukkan bahwa semakin kaburnya (taram-temaram) bayang-bayang keindahan (pelangi).

3. Imaji

Faktor emotif berikutnya adalah imaji. Imaji adalah penggunaan kata yang memiliki lambang-lambang yang dapat kita indra. Wachid (2010:131) menyatakan bahwa "Dalam sajak, citraan dipergunakan dalam dua pengertian, yakni sebagai pengalaman indra, dan bentuk bahasa yang dipergunakan untuk menyampaikan pengalaman indra itu." Dalam hal ini, Sapardi menggunakan seluruh imaji dalam kumpulan puisinya. Beberapa iamjia yang sering digunakan adalah sebagai berikut. Yang pertama adalah imaji pendengaran, berikut ini adalah penggalan puisi "Pada Suatu Malam" yang mengandung imaji pendengaran.

ia pun berjalan ke barat. selamat malam, solo,

katanya sambil merunduk.

seperti didengarnya sendiri suara sepatunya (I1)

satu per satu.

(Damono, 2013:5)

Pratiwi (2016:96) memyatakan bahwa "Citraan pendengaran adalah citraan yang timbul dari indra pendengaran." Penggalan puisi di atas dikatakan memiliki imaji pendengaran karena terdapat kata seperti didengarnya sendiri suara sepatunya. Kata tersebut membangkitkan imajinasi pembaca sehingga timbulnya efek suara. Yang kedua adalah imaji pengelihatan.

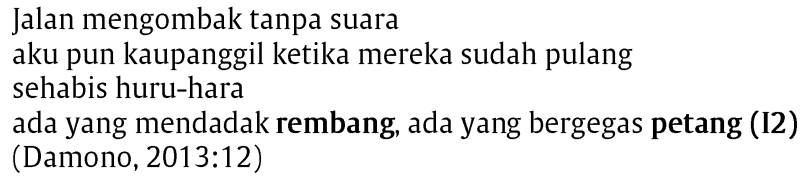

Menurut Sayuti (1985:111) citra pengelihatan atau citra netra atau citra dinulu adalah citra yang berhubungan dengan indera pengelihatan. Penggalan puisi berjudul "Tengah Hari" di atas dikatakan memiliki imaji pengelihatan karena adanya kata rembang dan petang. Rembang dan petang memiliki makna yang sama, yakni menjelang sore. Ketika melihat kedua kata tersebut, tentu pembaca mengimajikannya dengan keadaan dimana matahari mulai terbenam.

\section{Kata konkret}

Kata konkret adalah kata yang digunakan untuk mengkonkretkan perasaan atau hal abstrak lainnya. Menurut Wisang (2014:25) kata konkret adalah kata-kata yang dilihat secara denotatif sama tetapi secara konotatif tidak sama menurut situasi dan kondisinya. Penggalan puisi di bawah ini adalah contoh dari penggunaan kata konkret.

aku ingin mencintaimu dengan sederhana:

dengan kata yang tak sempat diucapkan (K1)

kayu kepada api yang menjadikannya abu (K1)

(Damono, 2013:105) 
Penggunaan kata konkret dalam puisi berjudul "Aku Ingin" di atas bertujuan untuk mengkonkretkan cinta si aku yang sederhana. Cinta si aku di ibaratkan seperti kata yang tak sempat diucapkan kayu kepada api yang menjadikannya abu, maksudnya cinta si aku tidaklah pamrih meskipun si aku bersedia menyerahkan seluruh kehidupannya kepada orang yang ia cintai.

\section{Majas}

Faktor emotif yang menggunakan kata-kata konotatif untuk memberikan fungsi estetis dan menyampaikan makna secara tersembunyi. Pratiwi (2016:78) menyatakan bahwa "Bahasa kias (majas) adalah Bahasa yang menggunakan kata-kata kiasan, artinya bahwa bahasa tersebut membandingkan dan menghubungkan sesuatu dengan hal yang lain sehingga tidak hanya menghasilkan makna secara harfiah." Makna yang tersembunyi inilah yang menjadikan puisi berbeda dari karya sastra lainnya. Berikut ini adalah majas yang sering digunakan.

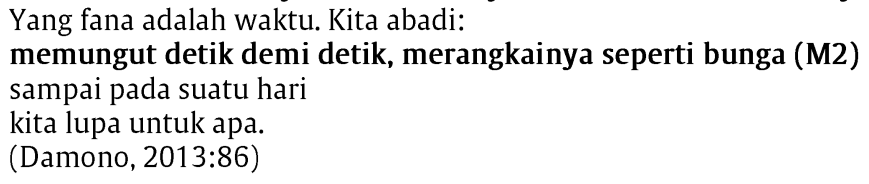

Pertama adalah metafora. Menurut Sayuti (1985:75) menyatakan bahwa "pada metafora perbandingannya bersifat implisit, tersembunyi di balik ungkapan harfiahnya." Dalam puisi berjudul "Yang Fana Adalah Waktu" di atas dianggap memiliki metafora karena membandingkan dua hal secara langsung. Dalam hal ini yang dibandingkan adalah detik demi detik yang diibaratkan sebagai benda yang dapat dipungut dan dirangkai seperti bunga. Perbandingan tanpa menggunakan kata pembanding itulah metafora.

Tuan Tuhan, bukan? Tunggu sebentar, (M4)

saya sedang keluar.

(Damono, 2013:87)

Kedua adalah majas personifikasi. Hal ini berasal dari kata person yang berarti manusia. Menurut Waluyo (1987:85), dalam personifikasi, benda dianggap sebagi manusia atau persona, atau di"personifikasi"kan. Majas personisikasi pada puisi berjudul "Tuan" di atas terdapat pada kata Tuan dan Tuhan yang seolah-olah menggambarkan bahwa Tuhan itu seperti manusia. Puisi di atas merupakan sindiran bahwa jika Tuhan sudah berkehendak tak bisa lagi dinegosiasikan seperti halnya dengan manusia.

6. Bunyi

Faktor emotif bunyi dalam puisi dapat dilakukan dengan berbagai cara. Beberapa di antaranya dapat menggunakan pengaturan rima, ritme, dan metrum. Selain itu, dapat juga dengan pengaturan asonansi, konsonansi, dan aliterasi. Akan tetapi, bunyi yang dihasilkan pada dasarnya hanya ada dua, yakni bunyi nyaring dan parau. Di bawah ini adalah penggalan puisi yang memiliki bunyi nyaring dan parau.

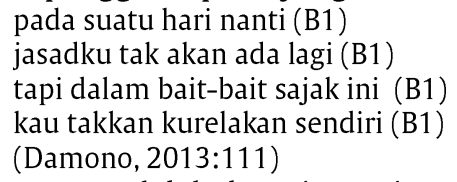

Yang pertama adalah bunyi nyaring. Jika suatu kombinasi vokal-konsonan berfungsi melancarkan ucapan, mempermudah pengertian serta untuk mempercepat irama, disebut efoni (Brooks dalam Sayuti, 1985:49). Euphony biasanya untuk menggambarkan perasaan cinta atau hal-hal yang menggambarkan kesenangan lainnya. Dalam penggalan puisi berjudul "Ketika Jari-jari Bunga Terbuka" di atas ada pengaturan rima dengan penggunaan huruf $i$ di setiap akhir baris. Bunyi $i$ tersebut menghasilkan nuansa liris yang menimbulkan efek perasaan terharu setelah dibaca. Bunyi $i$ merupakan pendukung dari isi puisi tersebut. Bunyi $i$ termasuk bunyi yang nyaring karena tidak pengang ketika didengarkan saat dilisankan.

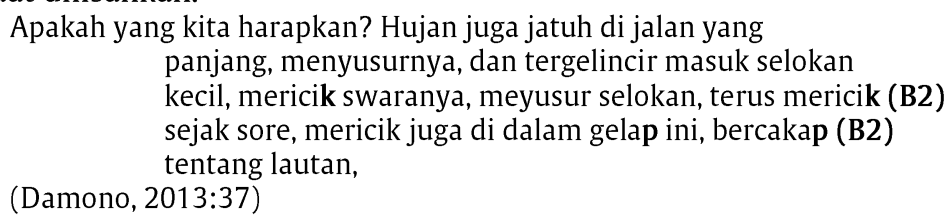

Yang kedua adalah bunyi parau. Menurut Sayuti (1985:51) ada pula sekelompok bunyi konsonan, biasanya k, p, $\mathrm{t}, \mathrm{s}$, yang justru fungsinya menghalangi kelancaran ucapan dan memperlambat irama yang disebut dengan kakofoni (cacopgony). Dalam penggalan puisi berjudul "Hujan Dalam Komposisi, 2" di atas terdapat bunyi parau yang dilakukan dengan cara konsonansi. Pada baris ketiga terjadi konsonansi bunyi $k$ dan pada baris keempat terjadi konsonansi bunyi p. Bunyi-bunyi tertutup tersebut mengakibatkan suara-suara parau yang menimbulkan kesan menakutkan.

\section{Sarana retorik}

Faktor emotif lainnya adalah sarana retorik. Sarana retorik ini berfungsi untuk mendukung makna yang ingin disampaikan olah penyair. Di bawah ini adalah beberapa sarana retorik yang sering digunakan dalam kumpulan puisi "Hujan Bulan Juni" karya Sapardi Djoko Damono.

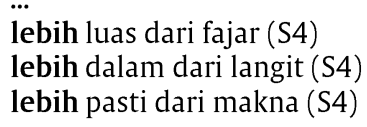


Pertama adalah paralelisme. Paralelisme adalah pengulangan kata atau kelompok kata tertentu yang dilakukan dalam beberapa baris puisi. Menurut Cohen (dalam Badrun, 1989:47) paralelisme ialah persejajaran antara dua bagian kalimat yang sama, perulangan susunan kalimat atau perulangan kata-kata pada awal puisi dan menimbulkan musik. Pada penggalan puisi berjudul "Terbangnya Burung" di atas terdapat pengulangan kata lebih. Kata lebih itulah yang merupakan paralelisme.

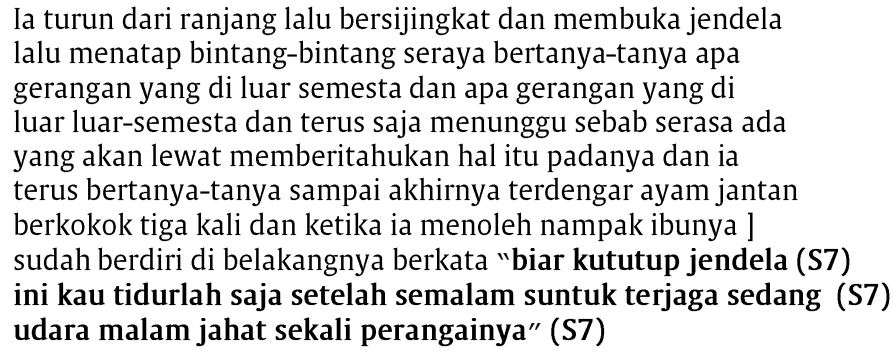

(Damono, 2013:60)

Kedua adalah paradoks. Perrine (dalam Badrun, 1989:51) mengatakan bahwa paradoks adalah sebuah bentuk pertentangan mengenai situasi atau pernyataan yang masih mengandung kebenaran. Berbeda halnya dengan hiperbola, paradoks biasanya lebih sering digunakan untuk menyindir atau membalikkan keadaan. Pada penggalan puisi berjudul "Catatan Masa Kecil, 3" di atas ditunjukkan bahwa si ia sangat kagum dengan indahnya malam yang dikelilingi bintang-bintang, bahkan ia semakin ingin untukmelihat keindahan di luar semesta. Akan tetapi, si ibu mengatakan sebaliknya, ia memberitahukan bahwa udara malam itu jahat sekali perangainya. Pembalikan keadaan menyenangkan menjadi buruk, ataupun buruk menjadi menyenangkan itulah yang disebut dengan paradoks.

\section{Nilai Emotif dalam Kumpulan Puisi "Hujan Bulan Juni" Karya Sapardi Djoko Damono}

Nilai emotif adalah perasaan yang menempel pada sebuah makna. Nilai emotif puisi berarti perasaan yang terkandung di dalam sebuah makna puisi tertentu. Berikut ini adalah beberapa perasaan yang sering ditemukan dalam kumpulan puisi "Hujan Bulan Juni" karya Sapardi Djoko Damono.

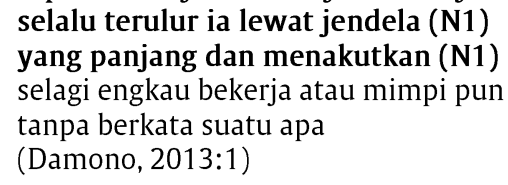

Pertama adalah perasaan takut, dalam penggalan puisi berjudul "Tangan Waktu" di atas waktu digambarkan sebagai sesuatu yang menakutkan. Waktu diibaratkan sebagai seseorang yang memiliki tangan panjang dan menakutkan. Waktu akan bersiap merenggut kehidupan kita setiap saat. Perasaat dihantui sehingga membuat cemas itulah yang disebut dengan takut.

bila saja kautanya: mau apa

berarti terlalu jauh kau sudah terbawa

sebelum sungguh menjadi sadar

bahwa sudah terlanjur terlantar (N2)

(Damono, 2013:1)

Kedua adalah kesepian. Dalam penggalan puisi berjudul "Tangan Waktu" di atas digambarkan tentang seseorang yang terseret oleh arus kehidupan, terbukti pada kata mau apa dan kau sudah terbawa. Setelah terlena dengan arus kehidupan tersebut, maka seseorang tersebut akan tertinggal oleh teman-temannya sehingga ia merasa terlantar. Perasaan terlantar tanpa orang disekitarnya dan menjalani hidup sendiri itulah yang disebut dengan kesepian.

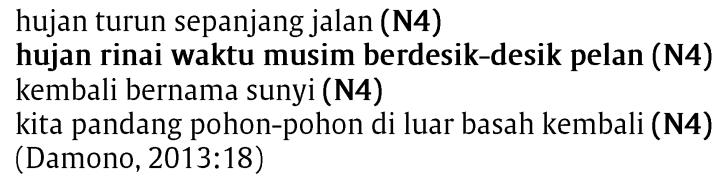

Ketiga adalah perasaan nyaman atau tentram. Perasaan ini terjadi apabila suasana di sekitar damai dan tentram tanpa ada gangguan. Dalam puisi berjudul "Hujan Turun Sepanjang Jalan" di atas pada baris hujan rinai waktu musim berdesik-desik pelan menunjukkan adanya suasana nyaman. Kenyamanan dalam puisi tersebut terjadi ketika musim berdesik-desik pelan artinya keadaan manusia tidaklah diburu-buru oleh waktu lagi. Seperti kondisi ketika hujan, semua orang yang ingin beraktivitas beristirahat sejenak agar tidak terkena hujan. Sambil beristirahat mereka menikmati hujan tersebut.

Kita berjingkat lewat 


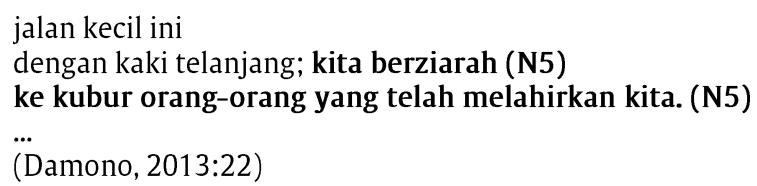

Keempat adalah perasaan sedih. Perasaan ini terjadi ketika psikologi manusia merasakan kehilangan, kekurangan, putus asa, taupun hal negatif lainnya. Dalam penggalan puisi berjudul "Ziarah" di atas, sedih terjadi karena kehilangan orang-orang yang telah melahirkan kita. Perasaan yang tersirat dalam puisi tersebut adalah perasaan sedih ketika kita berziarah ke makan orang yang mencintai dan berjasa kepada kita. bumi tak pernah membeda-bedakan. seperti ibu yang baik, (N10) diterimanya kembali anak-anaknya yang terkucil dan (N10) membusuk, seperti halnya bangkai binatang; pada suatu hari (N10) seorang raja, atau jenderal, atau pedagang, atau klerek- (N10) sama saja;

(Damono, 2013:10)

Kelima adalah perasaan senang. Perasaan ini terjadi ketika seseorang yang merasa lega atas sebuah kejadian yang menimpanya. Dalam penggalan puisi berjudul "Tentang Seorang Penjaga Kubur Yang Mati" di atas perasaan senang terjadi ketika ia merasa diterima di bumi, terbukti dari kata "bumi tak pernah membeda-bedakan. seperti ibu yang baik,". Bumi diibaratkan seperti ibu yang selalu menerima anak-anaknya seburuk apapun anaknya itu.

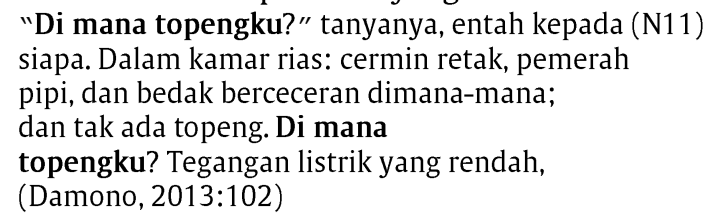

Keenam adalah perasaan bingung. Rasa bingung terjadi ketika manusia ingin mengetahui sesuatu tetapi ia tetap tidak mengetahuinya meskipun telah dilakukan dengan berbagai cara. Dalam penggalan puisi berjudul "Topeng" di atas penyair merasa bingung dalam mencari topengnya. Ia telah mencari kemana-mana tetapi ia tetap tidak menemukan topeng tersebut. Makna yang tersirat dari hal tersebut adalah tentang ketidakmampuan manusia untuk menentukan jati dirinya, manusia tersebut hanya hidup sebagai topeng belaka. Topeng tidak ditemukan dimanapun karena topeng tersebut telah menyatu pada wajah si aku.

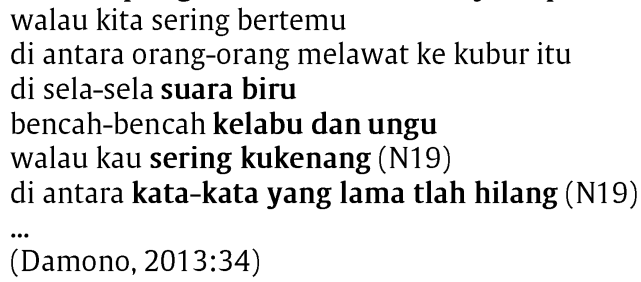

Ketujuh adalah rasa rindu, misalnya pada puisi yang berjudul "Sonet: Y". Perasaan ini terjadi ketika kita telah lama tak berjumpa dengan orang dan kita ingin menemuinya di saat tertentu. Rasa rindu kepada orang yang telah meninggal dalam puisi di atas digambarkan dengan di sela-sela suara biru/bencah-bencah kelabu dan ungu/walau kau sering kukenang/di antara kata-kata yang lama tlah hilang. Warna biru adalah simbol rasa rindu dan warna kelabu dan ungu adalah lambang dari keresahan terhadap kenangan terhadap orang-orang yang telah meninggal tersebut.

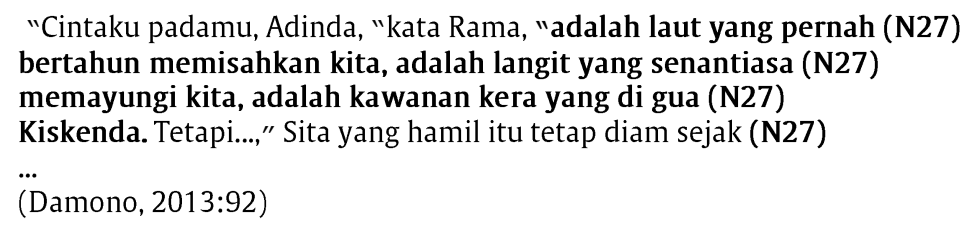

Kedelapan adalah perasaan sayang. Perasaan sayang adalah perasaan yang merasa nyaman dan bahagia terhadap keberadaan manusia ataupun makhluk lain di dekatnya. Pada penggalan puisi di atas rasa sayang yang digambarkan adalah cinta Rama terhadap Sita. Dalam penggalan puisi berjudul "Benih" di atas Rama menggambarkan cintanya yang begitu dalam dengan "adalah laut yang pernah bertahun memisahkan kita, adalah langit yang senantiasa memayungi kita, adalah kawanan kera yang di gua Kiskenda. Tetapi..".

Dari semua faktor emotif dan nilai emotif tersebut hanya diambil yang sering muncul saja. Masih banyak yang lagi faktor dan nilai emotif di dalamnya. Akan tetapi, hal tersebut tidak dapat dibahas dalam artikel ini dikarenakan adanya pembatasan jumlah halaman dalam penelitian ini.

\section{PENUTUP \\ Kesimpulan.}


1. Faktor emotif yang digunakan dalam kumpulan puisi ini sangatlah variatif sehingga membuat puisi-puisinya tidak membosankan. Namun, dari sekian banyak faktor emotif tersebut yang paling menonjol adalah kata konkret dan imaji pengelihatan. Hal ini menunjukkan bahwa ada konkretisasi hal-hal yang bersifat emotif atau imajinatif. Pengkonkretan itu sebagian besar ditunjukkan dengan menggunakan imaji pengelihatan.

2. Dalam kumpulan puisi tersebut terlihat bahwa peyair mampu mengungkapkan perasaannnya dalam berbagai situasi. Perasaan yang menonjol dalam kumpulan puisi di atas adalah rasa kesepian. Hal ini terlihat dari konkretisasi setting yang yang menunjukkan tanda-tanda sepi dan sunyi. Sebagian besar judul-judul puisinya juga berisi hal-hal yang menunjukkan kesepian, seperti rasa kesendirian di pemakaman, di belakang jenazah, dan tempat-tempat yang

Saran bernilai sepi dan sunyi lainnya.

1. Penelitian ini jika dikaji secara perbaris akan memerlukan waktu yang lama. Sehingga dianjurkan untuk meneliti perpuisi saja.

2. Pengkajian faktor emotif ini jika dilakukan dengan cara mengkaji perbaris, memerlukan pengecekan berulang-ulang untuk mendapatkan hasil yang valid.

3. Faktor emotif ini dapat juga digunakan dalam pembelajaran untuk mengajarkan kepada siswa tentang cara mengungkapkan perasaan yang indah melalui tatabahasa yang indah.

4. Faktor emotif dalam penelitian ini adalah faktor emotif dalam kajian stilistika. Jika dikaitkan dengan pengkajian faktor emotif dalam karya satra lainnya atau dalam genre teks lainnya, maka penelitian ini sangatlah berbeda karena dalam karya tulis lainnya, pengkajian faktor emotif ini menggunakan kajian semantis. Dengan begitu, penelitian ini dapat digunakan sebagai wawasan baru dalam pengkajian faktor emotif.

\section{DAFTAR RUJUKAN}

Arikunto, S. 2010. Prosedur Penelitian. Yogyakarta: Rineka Cipta.

Badrun, Ahmad. 1989. Teori Puisi. Jakarta: Depdikbud.

Fajarina, Dian Fitra. 2012. Ekspresi Pengalaman Kejiwaan Pengarang dalam Naskah Drama Indonesia. Skripsi, Jurusan Sastra Indonesia, Fakultas Sastra, Universitas Negeri Malang.

Fransiska, Oki Maria. 2010. Penggunaan Gaya Bahasa Kias Pada Novel Sang Pemimpi Tetralogi (Kajian Stilistika) Karya Andrea Hirata. Skripsi, Jurusan Bahasa dan Sastra Indonesia, Fakultas Sastra, Universitas Negeri Malang.

Pradopo, Rachmat Djoko. 1987. Pengkajian Puisi: Analisis Strata Norma dan Analisis Struktural dan Smiotik (Cetakan Keduabelas). Yogyakarta: Gadjah Mada University Press.

Prastowo, Andi. 2014. Metode Penelitian Kualitatif: dalam Perspektif Rancangan Penelitian (Cetakan Ketiga). Jogjakarta: Ar-Ruzz Media.

Pratiwi, Yuni, dkk. 2016. Membaca Estetik Puisi: Dasar Teori dan Model Pelatihan. Yogyakarta: Penerbit Ombak.

Sayuti, Suminto A. 1985. Puisi dan Pengajarannya (Sebuah Pengantar). Yogyakarta: IKIP Semarang Press.

Sayuti, Suminto A. 2015. Puisi Sebuah Pengantar Apresiasi. Yogyakarta: Penerbit Ombak.

Siswanto, Wahyudi. 2013. Pengantar Teori Sastra. Malang: Aditya Media Publishing.

Ullman, Stephen. 1977. Semantics: An Intoduction to the Science of Meaning. Terjemahan Sumarsono. 2014. Yogyakarta: Pustaka Pelajar.

Wachid, Abdul. 2010. Analisis Struktural Semiotik Puisi Surealis Religius D. Zawawi Imron. Yogyakarta: Gama Media.

Waluyo, Herman J. 1987. Teori dan Apresiasi Puisi. Jakarta: Erlangga.

Wisang, Imelda Olivia. 2014. Memahami Puisi Dari Apresiasi Menuju Kajian. Yokyakarta: Ombak.

Zulfikar, Moh. Fikri. 2014. Ekspresi Pengalaman Kejiwaan Penulis Puisi dalam Majalah Bobo. Skripsi, Jurusan Sastra Indonesia, Fakultas Sastra, Universitas Negeri Malang. 